\title{
Performance, carcass traits and non-carcass components of lambs fed different levels of crambe meal
}

\section{Desempenho, características de carcaça e componentes não-carcaça de cordeiros alimentados com diferentes teores de farelo de crambe}

\begin{abstract}
Vivian Maria Deval1; Angela Rocio Poveda-Parra2*; Erica Regina Rodrigues ${ }^{3}$; Gianne Evans Cunha ${ }^{1}$; Mirna Adriane Syperreck ${ }^{2}$; Leandro das Dores Ferreira da Silva4; Camila Cano Serafim³; Elias Rodrigues Cavalheiro Junior3; Odimári Pricila Prado-Calixto4; Ivone Yurika Mizubuti ${ }^{4}$
\end{abstract}

\section{Highlights}

The crambe meal diet did not affect the performance and carcass traits Carcass yield of lambs fed with $1,000 \mathrm{~g} \mathrm{~kg}^{-1} \mathrm{DM}$ of crambe meal was $453.0 \mathrm{~g} \mathrm{~kg}^{-1} \mathrm{DM}$ Crambe meal can be used at $1,000 \mathrm{~g} \mathrm{~kg}^{-1} \mathrm{DM}$ in concentrate diets of lambs.

\section{Abstract}

The goal of this study was to evaluate different levels of crambe meal $\left(0,330,670\right.$ and $1,000 \mathrm{~g} \mathrm{~kg}^{-1}$ dry matter [DM]) as a replacement for soybean meal in diets supplied to feedlot lambs, and their effects on performance, carcass traits and non-carcass components. Twenty-four castrated lambs weighing $18.2 \mathrm{~kg}$ at the beginning of the experiment were allocated in a completely randomized design. Diets were formulated to meet the requirements of the lamb for an average daily gain of $0.200 \mathrm{~kg}$. The roughage:concentrate ratio was 60:40, using Brachiaria dyctioneura hay as roughage. Dry matter intake, feed conversion, average daily gain, carcass traits and non-carcass components were evaluated. There was no effect of different levels of crambe meal replacing soybean meal on performance, carcass traits and non-carcass components, except heart weight. Replacement $1,000 \mathrm{~g} \mathrm{~kg}^{-1} \mathrm{DM}$ of soybean meal protein by crambe meal protein does not affect the performance, carcass traits, or non-carcass components.

Key words: Biofuel. Byproduct. Beef cuts. Sheep.

1 Master in Animal Science, Universidade Estadual de Londrina, UEL, PR, Brazil. E-mail: vmd79@hotmail.com; gianneevans@hotmail.com

2 PhD Animal Science, UEL, Londrina, PR, Brazil. E-mail: angelpov@gmail.com; syperreck@gmail.com

3 Students of Doctoral Course of the Postgraduate Program in Animal Science, UEL, Londrina, PR, Brazil. E-mail: erica. franconere@gmail.com; camilacanoserafim@hotmail.com; elias.cavalheiro@uel.br

${ }^{4}$ Profs. Drs., Animal Science Department, UEL, PR, Brazil. E-mail: leandro@uel.br; odimari@uel.br; mizubuti@uel.br

* Author for correspondence

Received: May 21, 2021 - Approved: Sept. 14, 2021 


\section{Resumo}

O objetivo foi avaliar diferentes teores de farelo de crambe (0,330, 670 e $1000 \mathrm{~g} \mathrm{~kg}^{-1} \mathrm{MS}$ ) em substituição ao farelo de soja na ração de ovinos confinados, sobre o desempenho, características de carcaça e componentes não-carcaça. Foram utilizados 24 cordeiros, machos, castrados, com peso médio inicial de 18,2 kg e aproximadamente quatro meses de idade, distribuídos em delineamento inteiramente casualizado. As rações foram formuladas para atender as exigências nutricionais para ganho de peso diário de 0, $200 \mathrm{~kg} \mathrm{dia}^{-1}$. A proporção volumoso:concentrado foi de 60:40, e o volumoso utilizado foi o feno de Brachiaria dyctioneura. Foram avaliados o consumo de matéria seca, conversão alimentar, ganho de peso diário, características de carcaça e componentes não-carcaça. Não houve efeito dos diferentes teores de substituição do farelo de soja pelo farelo de crambe sobre as variáveis de desempenho, características de carcaça e componentes não-carcaça, com exceção do peso do coração. A substituição de $1000 \mathrm{~g} \mathrm{~kg}^{-1} \mathrm{MS}$ da proteína do farelo de soja pela proteína do farelo de crambe não afeta o desempenho, características de carcaça e componentes não-carcaça.

Palavras-chave: Biodiesel. Cortes comerciais. Ovinos. Coproduto.

\section{Introduction}

High costs related to animal nutrition have motivated the search for alternative feed that can meet nutritional requirements without jeopardizing performance and meat quality. Agroindustrial residues have been used because of their good nutritive value and low environmental impact (Ajila et al., 2012). Plantbased biofuel production promotes substantial amounts of byproducts usable in animal diets, such as ethanol, glycerol, meals and cakes (Bomfim, Silva, \& Santos, 2009; Varanda, Pinto, \& Martins, 2011; Eliche-Quesada et al., 2012).

The concentrate is the most expensive item in feedlot sheep production. Therefore, agroindustrial and biofuel byproducts may replace corn and soybean, if they are rich in protein and fiber (Yang et al., 2021).

Crambe (CrambeabyssinicaHoechst) is a cruciferous plant with considerable potential for biofuel production (Goes, Carneiro, Silva, \& Lana, 2016). Crambe seed crushing generates a meal and cake that contains approximately $30 \%$ protein, and can be considered low cost to animal feed (Canova, Bueno, Moreira, Posseti, \& Brás, 2015). Crambe meal is lower in oil content than cake (Silva, 2013), and it contains high amounts of amino acids such as cysteine, methionine, lysine and threonine.

Several studies have been conducted to evaluate crambe cake in animal nutrition. Moreira, Santos, Pacheco, Rocha and Figueiredo (2020) analyzed increasing levels $(0,25,50$ and $75 \%)$ of crambe cake protein in the concentrate for lambs, concluded that it could be used as a protein replacement up to $75 \%$ of the crude protein concentrate without any negative effects on animal performance. Ítavo et al. (2016) evaluated different values of crambe cake as a replacement for soybean meal $\left(0,64,128\right.$ and $192 \mathrm{~g} \mathrm{~kg}^{-1}$ of dry matter) in lambs and reported that the addition of up to $192 \mathrm{~g} \mathrm{~kg}^{-1} \mathrm{DM}$ in the diet did not affect the performance or carcass quality.

The goal of this study was to evaluate the effects of adding crambe meal to feedlot lambs as a replacement for soybean meal on performance, carcass traits and non-carcass components. 


\section{Material and Methods}

The experiment was conducted at the Experimental Farm at the State University of Londrina (UEL) after approval by the Ethics Committee in Animal Use (protocolnr. 123/2010). The trial was conducted for $90 \mathrm{~d}$, and the lambs were weighed every $15 \mathrm{~d}$. For intake control, the diet offered and leftovers were weighed daily.

At the beginning of the trial, 24 castrated no breed defined (NBD) lambs, weighing $18 \pm 2.30 \mathrm{~kg}$, were dewormed and allocated to four pens in a completely randomized design. The lams had access to feed, water, and mineral supplements. The evaluated treatments were levels of crambe meal $(0,330,670$ and 1,000 $\mathrm{kg} \mathrm{DM}^{-1}$ ) as a replacement for soybean meal in the concentrate diet.

The chemical composition of the dietary ingredients was determined at the Animal Nutrition Laboratory of UEL, according to methodology described by the Association of Official Analytical Chemists [AOAC] (2016) (Table 1). Diets were calculated to be isonitrogenous with roughage:concentrate at a ratio of 60:40 (Table 1). Brachiaria dyctioneura hay was used as the roughage. Animal requirements were met according to the National Research Council [NRC] (2007). Metabolizable energy (ME) was calculated using the formula ME (Mcal kg-1 of DM) $=\mathrm{g} \mathrm{kg}^{-1}$ Total digestible nutrients (TDN) *0.0362.

\section{Table 1}

\section{Chemical composition of ingredients and experimental diets}

\begin{tabular}{|c|c|c|c|c|c|c|c|}
\hline \multirow{2}{*}{ Ingredients } & \multirow{2}{*}{$\begin{array}{c}\mathrm{DM} \\
\left(\mathrm{g} \mathrm{kg} \mathrm{NM}^{-1 *}\right)\end{array}$} & \multirow{2}{*}{$\begin{array}{c}\text { ME } \\
\text { Mcal kg DM-1 }\end{array}$} & $\mathrm{CP}$ & $\mathrm{EE}$ & NDF & ADF & $\mathrm{OM}$ \\
\hline & & & \multicolumn{5}{|c|}{$\left(\mathrm{g} \mathrm{kg} \mathrm{DM}^{-1}\right)$} \\
\hline B. dyctioneura hay & 860.60 & 1.933 & 89.30 & 14.60 & 734.20 & 495.4 & 930.30 \\
\hline Grounded corn & 900.70 & 3.113 & 96.00 & 46.60 & 128.80 & 14.90 & 954.00 \\
\hline Soybean meal & 833.10 & 3.092 & 500.00 & 16.00 & 150.00 & 100.00 & 932.60 \\
\hline Crambe meal & 897.60 & 2.121 & 370.70 & 34.00 & 301.80 & 163.30 & 897.60 \\
\hline \multirow{2}{*}{ Ingredients } & \multicolumn{7}{|c|}{ Crambe meal levels replacing soybean meal ( $\left.\mathrm{g} \mathrm{kg}^{-1} \mathrm{DM}\right)$} \\
\hline & \multicolumn{2}{|r|}{0} & 330 & & 670 & \multicolumn{2}{|c|}{1,000} \\
\hline B. dyctioneura hay & \multicolumn{2}{|c|}{600.00} & 600.00 & & 600.00 & \multicolumn{2}{|c|}{600.00} \\
\hline Grounded corn & \multicolumn{2}{|c|}{248.00} & 252.00 & & 257.40 & \multicolumn{2}{|c|}{256.70} \\
\hline Soybean meal & \multicolumn{2}{|c|}{140.00} & 94.00 & & 46.20 & \multicolumn{2}{|r|}{----} \\
\hline Crambe meal & \multicolumn{2}{|r|}{0.00} & 46.20 & & 94.00 & \multicolumn{2}{|c|}{140.00} \\
\hline Limestone & \multicolumn{2}{|r|}{11.60} & 6.80 & & 0.40 & \multicolumn{2}{|r|}{0.40} \\
\hline Urea & \multicolumn{2}{|r|}{0.40} & 1.20 & & 2.20 & \multicolumn{2}{|r|}{3.20} \\
\hline \multicolumn{8}{|c|}{ Chemical composition } \\
\hline $\mathrm{DM}\left(\mathrm{g} \mathrm{kg}^{-1} \mathrm{DM}\right)$ & \multicolumn{2}{|c|}{863.00} & 863.50 & & 863.33 & \multicolumn{2}{|c|}{859.10} \\
\hline $\mathrm{CP}\left(\mathrm{g} \mathrm{kg}^{-1} \mathrm{DM}\right)$ & \multicolumn{2}{|c|}{141.71} & 141.71 & & 141.71 & \multicolumn{2}{|c|}{142.71} \\
\hline ME (Mcal kg-1 DM) & \multicolumn{2}{|r|}{2.332} & 2.322 & & 2.315 & \multicolumn{2}{|c|}{2.289} \\
\hline $\mathrm{EE}\left(\mathrm{g} \mathrm{kg}^{-1} \mathrm{DM}\right)$ & \multicolumn{2}{|c|}{21.90} & 22.80 & & 23.40 & \multicolumn{2}{|c|}{26.80} \\
\hline NDF ( $\left.\mathrm{g} \mathrm{kg}^{-1} \mathrm{DM}\right)$ & \multicolumn{2}{|c|}{496.70} & 456.80 & & 490.70 & \multicolumn{2}{|c|}{481.60} \\
\hline ADF ( $\left.\mathrm{g} \mathrm{kg}^{-1} \mathrm{DM}\right)$ & \multicolumn{2}{|c|}{314.89} & 317.89 & & 362.59 & \multicolumn{2}{|c|}{323.89} \\
\hline
\end{tabular}

${ }^{*} \mathrm{DM}=$ Dry matter; $\mathrm{NM}=$ natural matter; $\mathrm{OM}=$ organic matter; $\mathrm{CP}=$ crude protein; $\mathrm{EE}=$ Ether extract; $\mathrm{ME}=$ Metabolizable energy; NDF= Neutral detergent fiber; $A D F=$ Acid detergent fiber. 
Animals were fed the total diet twice a day (7:30 $\mathrm{h}$ and 16:30 h), and the amount offered was adjusted daily to maintain $10 \%$ leftover relative to the total weight of feed provided to ensure intake without food availability restrictions. Both water and mineral supplements were provided ad libitum.

Mineral supplementation was provided using a brand product with the following content per kg: calcium (max.) 150g; phosphorus (min.) 65g; sodium (min.) 107g; sulphur (min.) 12g; magnesium (min.) 6,000mg; cobalt (min.) 175mg; copper (min.) 100mg; iodine (min.) $175 \mathrm{mg}$; manganese (min.) 1,440mg; selenium (min.) 27mg; zinc (min.) 6,000mg; iron (min.) 1,000mg; fluorine (max.) 650mg.

Animals were slaughtered at approximately $30 \mathrm{~kg}$ body weight (BW) at an inspected slaughterhouse in Rolândia (Paraná State). For a humane slaughter, animals were kept in a pen for $12 \mathrm{~h}$ before being stunned by electronarcosis, followed by bleeding, skinning and evisceration

Carcasses were individually weighed after slaughter (HCW = hot carcass weight) chilled for $24 \mathrm{~h}$ in a cold chamber at $2^{\circ} \mathrm{C}$, and weighed again (CCW = cold carcass weight). Cold carcass yield (CCY) was calculated as the percentage of hot and cold weight compared to the final weight (FW) (Osório, 2003).

The gastrointestinal tract was collected after slaughter and weighed both full and empty, to obtain the empty body weight (EBW). Visceral fat involved in the gastrointestinal tract was separated, weighed, and then classified as omental (rumen, reticulum, abomasum and omasum), mesenteric (small and large intestines) and peri-kidney fat (Cézar \& Sousa, 2007).
Carcass conformation was evaluated according to the methodology described by Luchiari (2000) and classified as follows: convex (6), highly accentuated muscularity; subconvex (5), intermediate; rectilinear (4), more pronounced muscular planes; concave (3), bony apophysis prominences; subconcave (2), thin with slight evidence of muscular planes; and industrial (1), extremely lean with evident bone bases. Carcass finishing was evaluated according to the abundance of fat cover: very plentiful (5), plentiful (4), intermediate (3), reduced (2) and very reduced (1) (Cézar \& Sousa, 2010). Both parameters were determined by comparison with figure standards.

For each half-carcass, chest depth (DCHEST), leg+hindshank length (LEGLEN), leg+hindshank perimeter (LEGPER), leg+hindshank depth (LEGDEP), arm length (ARMLEN), arm perimeter (ARMPER) and arm depth (ARMDEP) were determined (Osório, 2003). From the left half-carcass, pieces were separated according to commercial cuts: leg+hindshank, rib, shoulder and neck and weighed separately to calculate meat yield (McManus et al., 2010).

The loin area was obtained following a previously described method (Müller, 1980) by exposing Longissimus dorsi after a crosscut between the $9^{\text {th }}$ and $11^{\text {th }}$ ribs $(\mathrm{H}-\mathrm{H}$ section). Paper was placed under the muscle, and an outline of the area was drawn with a pen to determine the loin area. For the same section the thickness of the fat cover was measured using a caliper.

The data were submitted to an analyses of variance and regression (at 5\% significance level) using the Statistical Analysis System software [SAS] (1996). 


\section{Results and Discussion}

\section{Animal performance}

There was no effect $(P>0.05)$ of crambe meal levels replacing soybean meal in concentrate diet (Table 2) on the average daily gain (ADG), average dry matter intake (DMI), DMI (\%BW), DMI (BW0.75) and feed conversion (FC) of the lambs.

\section{Table 2}

Performance of lambs fed different levels of crambe meal replacing soybean meal

\begin{tabular}{|c|c|c|c|c|c|c|}
\hline \multirow{2}{*}{ Parameter } & \multicolumn{4}{|c|}{ Crambe meal ( $\left.\mathrm{g} \mathrm{kg}^{-1} \mathrm{DM}\right)$} & \multirow{2}{*}{ CV (\%) } & \multirow{2}{*}{ P-value } \\
\hline & 0 & 330 & 670 & 1,000 & & \\
\hline IBM (kg) & 18.39 & 18.12 & 18.18 & 18.22 & 23.01 & NS \\
\hline FBW (kg) & 30.58 & 31.95 & 32.63 & 30.92 & 15.82 & NS \\
\hline ADG (kg day $\left.{ }^{-1}\right)$ & 0.14 & 0.16 & 0.17 & 0.15 & 22.11 & NS \\
\hline DMI (kg day $\left.{ }^{-1}\right)$ & 1.13 & 1.20 & 1.22 & 1.18 & 17.53 & NS \\
\hline DMI (\% BW) & 4.80 & 4.82 & 4.92 & 4.86 & 19.25 & NS \\
\hline DMI (BW $\left.{ }^{0.75}\right)$ & 0.10 & 0.11 & 0.11 & 0.11 & 4.53 & NS \\
\hline FC & 8.49 & 7.77 & 7.35 & 8.59 & 28.70 & NS \\
\hline
\end{tabular}

IBW, Initial body weight; FBW, Final body weight; ADG, Average daily gain; DMI, Dry matter intake; FC, Feed conversion; $\mathrm{CV}$, Coefficient of variation.

The DMI varied as expected (1$1.3 \mathrm{~kg} \mathrm{~d}^{-1}$ ). These results were caused by isonitrogenous diets with similar energy content because diet quality can control the intake according to energy and digestibility (Van Soest, 1994). Despite the substantial intake, the ADG was lower than the $0.200 \mathrm{~kg}$ $\mathrm{d}^{-1}$, recommended by the National Research Council (NRC, 2007) was not affected by levels of crambe meal. However, the high amounts of Neutral detergent fiber (NDF) from $B$. dyctioneura hay and NDF and acid detergent fiber (ADF) from whole diets lowered the digestible feed supply. Crambe meal lipid content might also promote greater feed intake.

Voluntary intake is responsible for $60 \%$ to $90 \%$ of digestible energy intake variation and is associated with animal potential and energetic requirement, as well as to the physical capacity of the digestive tract, which is proportional to both weight and size of the animal (Resende, Silva, Lima, \& Teixeira, 2008; Ferreira et al., 2013).

Several factors affect food intake, and can be related to the animal itself, such as the interaction of brain signals and the satiety center, animal ingestive behavior and the environment (Ferreira et al., 2013). However, performance is derived from intake, digestibility and nutrient metabolism.

Crambe byproducts contain 80 - $100 \mathrm{~g}$ $\mathrm{kg}^{-1}$ of glucosinolates, and their presence may reduce intake because of their low palatability. However, such antinutritional factors can be inactivated in $64 \%$ to $79 \%$ by tempering, 
dehulling, flaking, conditioning, expanding and roasting the crambe meal (Fundação Mato Grosso do Sul [Fundação MS], 2011). Therefore, the production of the crambe meal used in this trial probably reduced the glucosinolate at levels that did not jeopardize the DMI.

Similar results were reported by Moreira et al. (2020) who evaluated increasing levels of crambe meal protein $(0,25,50$ and $75 \%$ of DM) as a replacement for concentrate protein in diets of lambs. They did not detect effect of crambe meal protein on intake, and concluded that crambe meal protein could replace concentrate protein up to $75 \%$ without compromising animal performance. However, Ítavo et al. (2016) assessed different amounts of crambe meal $\left(0,64,128\right.$ and $\left.192 \mathrm{~g} \mathrm{~kg}^{-1} \mathrm{DM}\right)$ to replace soybean meal in lamb diets, and observed an increase in DMl as a function of replacement levels; however, there was no effect on weight gain. They concluded that up to $192 \mathrm{~g} \mathrm{~kg}^{-1}$ of crambe meal did not change animal performance. Sousa (2014) studied several levels of crambe meal inclusion $(0,28$, 37 and $52 \%$ ) in diets fed to lambs and observed a decrease in intake and feed efficiency.

\section{Carcass traits}

There was no effect of different amounts of crambe meal replacing soybean meal in the concentrate diet $(P>0.05)$ on carcass traits, weight and meat yield (Table 3 ).
Both hot and cold carcass weights that affected other parameters such as fat content, conformation and commercial cuts, were evaluated. Carcass yield was the percentage ratio of carcass weight and live animal weight. It is considered an important indicator of edible portion profitability, and can vary according to breed, sex, slaughter weight and production system (Fernandes et al., 2013; Paula, Macedo, \& Simioni, 2017). The observed values were comparable to those reported by Astiz (2008), who stated that lamb carcass yield could vary from 40 to $60 \%$ depending on crossbreeding and the production system.

When evaluating four levels of crambe meal $\left(0,64,128\right.$ and $\left.192 \mathrm{~g} \mathrm{~kg}^{-1}\right)$ as a replacement for soybean meal in diets of lambs and ewes, Ítavo et al. (2016) found effect on both slaughter and cold carcass weights as a function of sex with greater values for lambs; however, crambe meal did not affect these variables.

Finishing evaluation consists of carcass adiposity and conformation as visualbased parameter (Ramirez-Retamal, \& Morales, 2014), and they can predict the edible portion of the carcass (Cordão, Cézar, Silva, Bandeira, \& Moraes, 2012). The observed finishing values indicated low fat with sub-concave conformation, and very lean carcasses with insufficient muscle cover. In young animals, fat deposition occurs late and can be influenced by age and sex (Cordão et al., 2012). 
Table 3

Carcass traits of lambs fed different levels of crambe meal replacing soybean meal

\begin{tabular}{|c|c|c|c|c|c|c|}
\hline \multirow{2}{*}{ Parameter } & \multicolumn{4}{|c|}{ Crambe meal ( $\left.\mathrm{g} \mathrm{kg}^{-1} \mathrm{DM}\right)$} & \multirow{2}{*}{ CV (\%) } & \multirow{2}{*}{ P-value } \\
\hline & 0 & 330 & 670 & 1,000 & & \\
\hline Final body weight, kg & 30.58 & 31.95 & 32.63 & 30.92 & 15.82 & NS \\
\hline Hot carcass weight, kg & 14.45 & 14.62 & 14.92 & 14.58 & 19.21 & NS \\
\hline Cold carcass weight, $\mathrm{kg}$ & 13.85 & 14.15 & 14.38 & 14.02 & 19.43 & NS \\
\hline Cold carcass yield, \% & 45.08 & 44.00 & 43.90 & 45.30 & 5.69 & NS \\
\hline Cold loss index, \% & 4.12 & 3.25 & 3.61 & 3.85 & 33.48 & NS \\
\hline Conformation score & 2.16 & 2.00 & 2.16 & 1.83 & 41.70 & NS \\
\hline Finishing & 2.00 & 2.16 & 2.66 & 2.66 & 29.01 & NS \\
\hline Chest depth, $\mathrm{cm}$ & 24.83 & 25.00 & 25.66 & 25.50 & 7.17 & NS \\
\hline Leg+hindshank length, cm & 34.16 & 35.50 & 34.50 & 35.25 & 8.20 & NS \\
\hline Leg+hindshank depth, cm & 8.80 & 8.96 & 8.53 & 8.58 & 15.60 & NS \\
\hline Leg+hindshank perimeter, cm & 37.93 & 37.41 & 38.63 & 38.00 & 6.02 & NS \\
\hline Arm length, $\mathrm{cm}$ & 18.83 & 19.83 & 19.55 & 20.13 & 9.87 & NS \\
\hline Arm depth, $\mathrm{cm}$ & 4.01 & 4.66 & 4.11 & 3.91 & 12.77 & NS \\
\hline Arm perimeter, $\mathrm{cm}$ & 16.53 & 16.93 & 16.06 & 17.26 & 7.94 & NS \\
\hline Depth of Longissimus dorsi, $\mathrm{cm}$ & 6.18 & 6.08 & 6.35 & 6.35 & 13.85 & NS \\
\hline Length of Longissimus dorsi, $\mathrm{cm}$ & 2.55 & 2.38 & 2.50 & 2.67 & 9.52 & NS \\
\hline Muscle fat thickness, $\mathrm{mm}$ & 2.83 & 3.16 & 3.16 & 3.33 & 36.37 & NS \\
\hline Loin eye area, cm2 & 6.33 & 6.16 & 6.83 & 6.75 & 15.85 & NS \\
\hline \multicolumn{7}{|c|}{ Weight of cuts } \\
\hline Leg+hindshank, kg & 4.46 & 4.61 & 4.61 & 4.58 & 19.51 & NS \\
\hline Rib, kg & 5.79 & 5.98 & 6.32 & 6.25 & 20.30 & NS \\
\hline Shoulder, kg & 2.79 & 2.86 & 2.94 & 2.75 & 18.40 & NS \\
\hline Neck, kg & 0.93 & 1.12 & 1.03 & 1.05 & 19.75 & NS \\
\hline \multicolumn{7}{|c|}{ Meat yield } \\
\hline Leg+hindshank,\% & 31.91 & 31.62 & 30.93 & 30.27 & 4.02 & NS \\
\hline Rib, \% & 41.22 & 41.03 & 42.41 & 42.67 & 4.61 & NS \\
\hline Shoulder, \% & 20.08 & 19.71 & 19.72 & 18.84 & 6.36 & NS \\
\hline Neck, \% & 6.79 & 7.64 & 6.93 & 7.20 & 11.85 & NS \\
\hline
\end{tabular}

$\mathrm{CV}=$ Coefficient of variation.

The ideal subcutaneous fat thickness for lambs has not yet been established because of carcass weight variation, but it varies 1 to $10 \mathrm{~mm}$ (Cezar \& Souza, 2007). In this trial, was $3 \mathrm{~mm}$, indicating an average fat content according to the Cezar and Souza (2007) classification. The loin eye area helps evaluated of muscle quantity and distribution, and is positively related to yield. The Longissimus dorsi presents late development; 
therefore, it is indicated for loin eye area measurement (Gois et al., 2019). Researchers have reported mean values from 7.51 to 14.49 $\mathrm{cm}^{2}$ in sheep carcasses, although slaughter age and animal growth may affect this index (Jucá et al., 2016).

Lambs carcasses can be purchased either as a whole or as pieces. Prime cuts come from the Leg+hindshank and loin, which present good palatability and high muscle to bone and muscle to fat ratios. Ribs and shoulder are subprime cuts, with similar palatability of prime cutes, but lower muscle yield and a greater portion of bones and fat. The neck is a third-class meat cut, with a greater proportion of bone, fat and tendons (Cesco, Macedo, Batista, Castro, \& Silveira, 2012; Gois et al. 2019). The yield of carcass components can be influenced by sex and live weight. When lambs have similar weights, meat cut yields are usually similar (Gois et al., 2019); the same was observed in this trial. According to Alves et al. (2015) and Carvalho et al. (2016) when animals are slaughtered at lighter BWs, greater muscle and lower fat yields are presented because of tissue relationship.

When testing four values $(0,28,37$ and $52 \%$ ) of crambe meal added to the diet, Sousa (2014) found $2.12 \mathrm{~mm}$ of fat thickness and decreasing effect on shoulder weight as a function of the crambe meal levels, but he assigned such results to the age and weight of the animal.

\section{Non-carcass components}

There was no effect $(P>0.05)$ of crambe meal levels on non-carcass components, except for heart weight (Table 4). Non-carcass components are inedible organs representing approximately $30 \%$ of the animal (Gois et al., 2019; Urbano et al., 2012).

Table 4

Weight and size of non-carcass components of lambs fed different levels of crambe meal replacing soybean meal

\begin{tabular}{|c|c|c|c|c|c|c|}
\hline \multirow{2}{*}{ Parameter } & \multicolumn{4}{|c|}{ Crambe meal ( $\left.\mathrm{g} \mathrm{kg}^{-1} \mathrm{DM}\right)$} & \multirow{2}{*}{ CV (\%) } & \multirow{2}{*}{ P-value } \\
\hline & 0 & 330 & 670 & 1,000 & & \\
\hline Feet (kg) & 0.75 & 0.87 & 0.80 & 0.82 & 19.49 & NS \\
\hline Skin (kg) & 2.72 & 3.28 & 3.03 & 2.85 & 20.56 & NS \\
\hline Head (kg) & 1.31 & 1.35 & 1.33 & 1.30 & 16.84 & NS \\
\hline Lungs (kg) & 0.38 & 0.38 & 0.45 & 0.39 & 25.71 & NS \\
\hline Heart (kg) & 0.13 & 0.20 & 0.12 & 0.13 & 28.68 & $P<0.051$ \\
\hline Kidneys (kg) & 0.10 & 0.10 & 0.10 & 0.13 & 19.59 & NS \\
\hline Spleen (kg) & 0.10 & 0.10 & 0.10 & 0.10 & 0.00 & NS \\
\hline Liver (kg) & 0.38 & 0.47 & 0.47 & 0.45 & 27.26 & NS \\
\hline GIT full (kg) & 8.31 & 8.70 & 9.12 & 8.33 & 14.88 & NS \\
\hline GIT empty (kg) & 3.00 & 3.58 & 3.28 & 3.15 & 14.71 & NS \\
\hline Small intestine (m) & 30.45 & 26.97 & 28.35 & 25.73 & 17.61 & NS \\
\hline Large intestine (m) & 5.94 & 6.48 & 5.54 & 6.54 & 27.30 & NS \\
\hline
\end{tabular}

GIT = gastrointestinal tract; ${ }^{1} \hat{Y}=0,13333+0,00667 x-0,00017759 x^{2}+0,00000111 x^{3} ; R 2=0,41$. 
According to Pompeu et al. (2013), viscera and organs present different growth rates during animal life compared to other parts of the body and can be influenced by diet. The relative weight of non-carcass components may vary from $40 \%$ to $60 \%$ of live weight, based on breed, sex, age, BW, type of partum, nutritional conditions and animal category (Lima, Carvalho, Batista, Ferreira, \& Ribeiro, 2015).

The difference in heart weight may be explained by the amount of erucic acid in crambe meal, even though it was not measured in this trial. Some oilseeds used for biofuel production have a wide range of erucic acid, a monounsaturated fatty acid with a 22-carbon chain. Animals can present heart damage when exposed to high concentrations of this acid (Colodetti, Martins, Rodrigues, Brinate, \& Tomaz., 2012).

\section{Conclusion}

Crambe meal can replace $1,000 \mathrm{~g} \mathrm{~kg}^{-1}$ of soybean meal in concentrate ration and can be the only protein source supplied to feedlot lambs, without losses in performance, carcass traits and non-carcass components.

\section{Acknowledgments}

To the National Council for Scientific and Technological Development (CNPq) for funding and providing research grant to Ivone Y. Mizubuti; to agronomist Carlos Pitol and to MS Foundation for donating the material of this trial (crambe meal); to Matsuda LTDA for donating the mineral supplement.

\section{References}

Ajila, C. M., Brar, S. K., Verma, M., Tyagi, R. D., Godbout, S., \& Valéro, J. R. (2012). Bioprocessing of agro-byproducts to animal feed. Critical Reviews in Biotechnology, 32(4), 1-19. doi: 10.3109/07388551.20 12.659172

Alves, L. G. C., Osório, J. C. S., Osório, M. T. M., Fernandes, A. R. M., Ribeiro, E. L. R., Cunha, C. M.,... Fuzikawa, I. H. S. (2015). Avaliação da composição regional e tecidual da carcaça ovina. Pubvet, 9(1), 6-19. doi: 10.22256/pubvet.v9n1.6-19

Association of Official Analytical Chemists (2016). Official methods of analytical of the association of official analytical of chemists. (20 $0^{\text {th }}$ ed.). Washington.

Astiz, C. S. (2008). Calidad de la canal y de la carne ovina y caprina y los gustos de los consumidores. Revista Brasileira de Zootecnia, 37(Spe), 143-160. doi: 10.1590/S1516-35982008001300018

Bomfim, M. A. D., Silva, M. M. C., \& Santos, S. F. (2009). Potencialidades da utilização de subprodutos da indústria de biodiesel na alimentação de caprinos e ovinos. Tecnologia e Ciência Agropecuária, 3(4), 5-26.

Canova, E. B., Bueno, M. S., Moreira, H. L., Posseti, R., \& Brás, P. (2015). Crambe cake (Crambe abyssinica hochst) on lamb diets. Ciência e Agrotecnologia, 39(1), 75-81. doi: 10.1590/S1413-7054201500 0100009

Carvalho, S., Zago, L. C., Pires, C. C., Martins, A. A., Venturini, R. S., Lopes, J. F.,... Moro, A. B. (2016). Tissue composition and allometric 
growth of tissues from commercial cuts and carcass of Texel lambs slaughtered with different weights. Semina: Ciências Agrárias, 37(4), 2123-2132. doi: 10.54 33/1679-0359.2016v37n4p2123

Cesco, G., Macedo, V. P., Batista, R., Castro, J. M., \& Silveira, A. P. (2012). Rendimentos dos cortes comerciais de carcaças e componentes extra carcaças de ovelhas de descarte submetidas a diferentes períodos no confinamento. Synergismus Scyentifica, 7(1), 1-4.

Cézar, M. F., \& Sousa, W. H. (2007). Carcaças ovinas e caprinas: obtenção, avaliação e classificação. Uberaba, MG: Ed. Agropecuária Tropical.

Cézar, M. F., \& Sousa, W. H. (2010). Proposta de avaliação e classificação de carcaças de ovinos deslanados e caprinos. Tecnologia \& Ciência Agropecuária, 4(4), 41-51.

Colodetti, T. V., Martins, L. D., Rodrigues, W. N., Brinate, S. V. B., \& Tomaz, M. A. (2012). Crambe: aspectos gerais da produção agrícola. Enciclopédia Biosfera, 8(14), 258-269.

Cordão, M. A., Cézar, M. F., Silva, L. S., Bandeira, P. A. V., \& Moraes, F. F. A. (2012). Acabamento de carcaça de ovinos e caprinos - Revisão bibliográfica. Agropecuária Científica no Semi-Árido, 8(2), 16-23. doi: 10.30969/ acsa.v8i2.196

Eliche-Quesada, D., Martínez-Martínez, S., Pérez-Villarejo, L., Iglesias-Godino, J., Martínez-García, C., \& Corpas-Iglesias, F. A. (2012). Valorization of biodiesel production residues in making porous clay brick. Fuel Processing Technology, 103, 166-173. doi: 10.16/j.fuproc.2011.11.013
Fernandes, G. A., Jr., Lobo, R. N. B., Madruga, M. S., Lobo, A. M. B. O., Vieira, L. S., \& Faco, O. (2013). Genotype effect on carcass and meat quality of lambs finished in irrigated pastures in the semiarid Northeastern Brazil. Arquivo Brasileiro de Medicina Veterinária e Zootecnia, 65(4), 1208-1216. doi: 10.433/1679-03 59.2013v34n6Supl2p3999

Ferreira, S. F., Freitas, M. D., Neto, Pereira, M. L. R., Melo, A. H. F., Oliveira, L. G., \& das Neves, J. T. N. (2013). Fatores que afetam o consumo alimentar de bovinos. Arquivos de Pesquisa Animal, 2(1), 9-19.

Fundação Mato Grosso do Sul (2011). Crambe: uma opção rentável para a Safrinha 2011 no Mato Grosso do Sul. Maracaju, MS. Recuperado de http://www.fundacaoms. org.brl

Goes, R. H. T. B., Carneiro, M. M. Y., Silva, K. C. B. da, \& Lana, R. P. (2016). Coprodutos de crambe (Crambe abyssinica Hoechst) na alimentação de ruminantes. Archivos de Zootecnia, 65(249), 7-16.

Gois, G. C., Pessoa, R. M. dos S., Santos, R. N., Cunha, D. de S., Araújo, C. de A., \& Macedo, A. de. (2019). Caracte $\neg$ rísticas de carcaça e componentes não-carcaça de ovinos: uma revisão. Arquivo de Ciências Veterinárias e Zoologia UNIPAR, 22(4), 139-146. doi: 10.25110/arqvet. v22i4.2019.7101

Ítavo, L. C. V., Souza, A. D. V., Fávaro, S. P., Ítavo, C. C. B. F., Petit, H. V., Dias, A. M.,... Roscoe, R. (2016). Intake, digestibility, performance, carcass characteristics and meat quality of lambs fed different levels of crambe meal in the diet. Animal Feed Science and Technology, 216, 40-48. doi: 10. 1016/j.anifeedsci.2016.02.015 
Jucá, A. F., Faveri, J. C., Melo, G. M., Fo., Ribeiro, A. L., Fo., Azevedo, H. C., Muniz, E. N.,... Pinto, L. F. B. (2016). Effects of birth type and family on the variation of carcass and meat traits in Santa Ines sheep. Tropical Animal Health and Production, 48(2), 435443. doi: 10.1007/s11250-015-0971-8

Lima, D. M., Jr., Carvalho, F. F. R., Batista, A. M. V., Ferreira, B. F., \& Ribeiro, M. N. (2015). Componentes do peso corporal de ovinos morada nova alimentados com feno de maniçoba ou feno de tifton. Revista Caatinga, Mossoró, 28(1), 239-246.

Luchiari, A., Fo. (2000). Pecuária da carne bovina. São Paulo: R. Vieira Gráfica \& Editora Ltda.

McManus, C., Louvandini, H., Landim, A., Melo, C. B., Seixas, L., Cardoso, M., \& Dallago, B. (2010). Abate e avaliação de carcaças em ovinos. Brasília: UNB.

Moreira, K. F., Santos, C. G., Pacheco, J. A. S., Rocha, A. A., \& Figueiredo, D. M. (2020). Desempenho, consumo e digestibilidade de nutrientes em cordeiros alimentados com níveis crescentes de farelo de crambe. Research, Society and Development, 9(10), e4539108859. doi: 10.33448/rsd-v9i10.8859

Müller, L. (1980). Normas para avaliação de carcaças e concurso de carcaças de novilhos. Santa Maria: Universidade Federal de Santa Maria.

National Research Council (2007). Nutrient requirements of small ruminants: sheep, goats, cervids and new world camelids. Washington: National Academic.

Osório, J. C. S. (2003). Produção de carne ovina: técnicas de avaliação "in vivo" e na carcaça ( $2 \mathrm{a}$ ed.), Pelotas: Editora Universitária PREC/UFPEL.
Paula, D. C., Macedo, V. H. M., \& Simioni, T. A. (2017). Características da carne na terminação de cordeiros em pastagens tropicais com suplementação Carcaça, desempenho, ovinos, raça, alimentação. Nutritime Revista Eletrônica, 14(5), 70537066.

Pompeu, R. C. F. F., Beserra, L. T., Cândido, M. J. D., Bomfim, M. A. D., Vieira, M. M. M., \& Andrade, R. R. (2013). Características da carcaça e dos componentes não-carcaça de ovinos alimentados com dietas contendo casca de mamona. Revista Brasileira de Saúde e Produção Animal, 14(3), 490-507. doi: 10.1590/S1519-99 402013000300011

Ramirez-Retamal, J., \& Morales, R. (2014). Influence of breed and feeding on the main quality characteristics of sheep carcass and meat: a review. Chilean Journal of Agricultural Research, 74(2), 225-233. doi: 10.4067/S0718-58392014000200015

Resende, K. T., Silva, H. G. O., Lima, L. D., \& Teixeira, I. A. M. A. (2008). Avaliação das exigências nutricionais de pequenos ruminantes pelos sistemas de alimentação recentemente publicados. Revista Brasileira de Zootecnia, 37(Sup. Esp.), 161-177. doi: 10.1590/S1516-3598 2008001300019

Silva, R. B. (2013). Substituição do farelo de soja por torta de crambe para ovinos em crescimento. Dissertação de mestrado, Universidade Federal de Lavras, Lavras, MG, Brasil. Recuperado de http:// repositorio.ufla.br/jspui/handle/1/1166

Sousa, V. S. (2014). Desempenho, características de carcaça e parâmetros sanguíneos em ovinos Santa Inês suplementados com Crambe abyssinica. 
Tese de doutorado, Universidade de Brasilia, Brasilia, DF, Brasil. Recuperado de https://repositorio.unb.br/handle/104 $82 / 16140$

Statistical Analysis System software (1996). User's guide. SASW Institute Inc. Cary, NC.

Urbano, S. A., Ferreira, M. A., Dutra, W. M., Jr., Andrade, R. P.X., Félix, S. C. R., Campos, J.T. S., \& Siqueira, M. C. B. (2012). Substituição do feno de tifton pela casca de mamona na dieta de ovinos: componentes não-carcaça. Arquivo Brasileiro de Medicina Veterinária e Zootecnia, 64(6), 1649-1655. doi: 10.1590/S010209352012000600034
Van Soest, P. J. (1994). Nutritional ecology of the ruminant (2nd ed.). Ithaca: Cornell University Press.

Varanda, M. G., Pinto, G., \& Martins, F. (2011). Life cycle analysis of biodiesel production. Fuel Processing Technology, 92(5), 10871094. doi: 10.1016/j. fuproc.2011.01.003

Yang, K., Quing, Y., Yu, Q., Tang, X., Chen, G., Fangt, R., \& Liu, H., 2021. By-products feeds: current understanding and future perspectives. Agriculture, 11(3), 207. doi: 10.3390/agriculture11030207 